\title{
Building bridges of peace in a J ewish-Palestinian Village in Israel: A role model for social justice and citizenship education
}

\author{
Grace Feuenverger \\ Ontario Institute for Studies in Education of the University of Toronto (OISE/UT)
}

\begin{abstract}
N eve Shalom/Wahat Al-Salam (the H ebrew and Arabic words for "O asis of Peace") is a village that began as an intercultural experiment. There, Jews and Pal estinians founded a community aimed at demonstrating the possibilities for living in peace- while maintaining their respective cultural heritages and languages. This paper explores the psychological, social and personal dimensions of this unique educational endeavour and draws the reader into the complex journey of Jews and Pal estinians who are trying to break down barriers of fear and mistrust that have saturated their daily existence. Feuerverger explore the deep woundings and sense of victimhood that both peoples - Jews and Palestinians - feel in very different ways. This ethnography was written from the heart and it certainly offers some hope in a time of darkness. It invites us all to become fellow dreamers of peace.
\end{abstract}

Key words: Peace education, conflict resolution, social justice, Hebrew-Arabic bilingual education, qualitative inquiry

RESUMEN

N eve Shalom/Wahat AI-Salam ("O asis de Paz") en hebreo y en arabe, es un pueblo que comenzó como un experimento intercultural. Alli, judios y palestinos fundaron una comunidad para demostrar que es posible vivir en paz, y al mismo tiempo mantener el patrimonio cultural y las tradiciones de cada pueblo. En el libro 'O asis de Sueños', resultado de nueve años de investigacion en las escuelas de la comunidad, la autora explora las dimensiones psicologicas, sociales y personales de esta original iniciativa educativa. Este artículo, que emerge de ' 0 asis de Sueños', invita a los lectores a introducirse en el complejo mundo de palestinos y judios que intentan derrumbar las barreras de miedo y desconfianza que han impregnado su existencia cotidiana. Feuerverger explora las profundas heridas y el sentimiento de victimización que los dos pueblos cargan, aunque de maneras bien diferentes. Este estudio etnografico fue escrito desde el corazon, ofrece un rayo de esperanza en tiempos de oscuridad, y nos invita a todos a transformarnos en soñadores de paz.

Descriptores: Educación para la paz, resolución de conflicto, justicia social, educación bilingue (árabehebreo), investigación cualitativa 
RÉSUMÉ

$\mathrm{N}$ eve Shalom/Wahat Al-Salam (les mots hebreux et arabes pour "O asis de rêves") est un village qui a débuté comme expérience interculturelle. Là, Juifs et Palestiniens ont fondé une communauté visant à démontrer les possibilités de vivre en paix - tout en conservant leurs langues et leurs héritages respectifs. Le livre "O asis de rêves" est le résultat d'une étude des écoles du village par l'auteur durant neuf ans Le livre explore les dimensions psychologiques, social es et personnelles de cette tentative éducative unique. Ce papier qui émerge de "O asis de rêves" entraîne le lecteur dans le cheminement complexe des Juifs et des Palestiniens qui essayent d'abattre les barrières de la peur et de la méfiance qui ont saturé leur existence journalière. Feuerverger explore les blessures profondes et le sentiment d'être victime que les deux peuples Juifs et Palestiniens - éprouvent de façons très différentes. Cette ethnographie a été écrite du fond du coeur et offre certainement une espérance dans un temps de noirceur. Elle nous invite tous à devenir compagnons de rêve de paix.

Mots-cléfs: Éducation à la paix, resolution de conflits, justice sociale, éducation bilingue hébreu-arabe, étude qualitatif

\section{Introduction}

$\mathrm{N}$ EVE SHALOM/WAHAT AL-SALAM - which are the Hebrew and Arabic words for "O asis of Peace" - is no ordinary place and neither are its educational institutions. It is a social-psychological experiment - a place where people with a certain level of education and personal conviction have chosen to come together to enact a collective vision of justice and caring. Their philosophy of a Jewish-Arab village in Israel, living and teaching peace and equality, is rooted in the democratic ideals of dialogue, negotiation and co-operative problem-solving. They are involved in an emotionally intense endeavour taking place 'on the cutting edge' of conflict resolution and education for peace. This paper, which emerges from my nine-year study, is an exploration into the desolate psychological landscape that Jews and Palestinians must navigate, and into their emotional journey towards breaking down the barriers of fear and mistrust that have saturated their daily existence. I explore the social and psychological dimensions of this educational odyssey towards peaceful coexistence, and discuss the sites of struggle and negotiation in the "border dialogues" that the participants have gradually created for themselves in their search to give equal expression to their national identities. I am concerned with looking at the way that these two national groups are cultivating new cultural spaces, new realms of discourse and new modes of thought. I study the epistemologically complex implications of understanding conflict resolution as a dialogical relation, the ultimate purpose of which is to create a geography of inclusion within the context of an Israeli community setting.

This paper is therefore devoted to the complexity and aesthetic of bilingual and bicultural education taking place in two educational institutions in a village where Jews and Palestinians are involved in peaceful co-existence both personally and professionally. M y aim is to focus on meaning-making as grounded in personal life history - that is, on the social, linguistic and cultural stories of my participants (and of myself ) in an attempt at a more nuanced view of peacemaking as the cornerstone of citizenship education. 


\section{Theoretical and methodological considerations}

My personal and professional life has been profoundly informed by the 'revolutionary' landscape of $\mathrm{N}$ eve Shalom/Wahat-AI-Salam. Indeed, the fieldwork experience has affected me in myriad ways and has allowed me to reflect upon my life story more deeply. My purpose here is to engage the discourse of peaceful co-existence in this Jewish-Palestinian village, as it relates to difference, sense of 'otherness', and conflict between two peoples yearning for home and safety. This excursion into the landscape of Jewish-Palestinian coexistence and conflict resolution focuses on narratives of longing for and belonging to a homeland: the Israeli homeland that currently exists and the Palestinian homeland that longs to be created. Both sides understand the troubling dimension of cultural displacement within their collective psyches.

This paper therefore focuses on an Israeli co-operative community where Jewish and Arab families live together in peace. W hat emerged was a shared narrative, a collaborative story about the teaching-learning experience within the two village schools, which exemplify a genuine attempt at partnership between these two national groups whose cultures are in geo-political and socio-historic conflict. For example, the use of both $\mathrm{H}$ ebrew and Arabic as media of instruction is a powerful symbol of inclusiveness and mutual respect, which has the capacity to construct and convey their commitment towards conflict resolution and peacemaking. I collected data in the midst of open dialogue and school partnerships. I focused on the collaborative relationships among the teachers that were promoted by the philosophy of this village and described the interconnected settings between teachers, students and parents. It was, in fact, a shared experience, which validated all participants and empowered them to explore their own participation in the peace education process. It also turned out that the experience of sharing their stories with me not only empowered my participants, but provided me, in the role of educational ethnographer, a fresh understanding of their quest for peaceful co-existence in the midst of deadly conflict in the wider society. The intention was to document the experiences of the participants and their facilitators through in-depth interviewing and participant-observation techniques in order to present a multi-layered picture of the very complex and arduous process towards coexistence. I was witness to the unconscious and conscious attempts of those involved in these bilingual, bicultural and binational education initiatives to break down personal, cultural and political barriers in congruence with the notion of "border pedagogy." These initiatives permitted teachers and students to rethink the spaces where dominant and subordinate groups are situated and thus to transform their own relationships as citizens.

\section{Theoretical framework}

There is very little qualitative research that focuses on a social grouping in which the residents are actively dedicated to issues of peacemaking in their daily lives. This paper intends to explore the social and psychological complexities of moral development through this specific educational experience. "M oral experience" here will refer to the 
"lived experience" (see D ilthey, 1910/1977 in Tappan \& Brown, 1989; Bakhtin, 1986) of my participants as they are confronted with everyday situations filled with moral conflicts, ambiguities and dilemmas. I have focused on giving meaning to their "lived experiences" by presenting them in narrative form. There is a growing understanding in the research literature of narrative as a powerful way of giving meaning to human life experiences (see for example, Geertz, 1988; Gilligan, 1982; N oddings, 1991; Polkinghorne, 1988; Sarbin, 1986; and so forth). This theoretical approach is congruent with Gilligan's focus on the analysis of moral voice and development by using narrative as a vehicle to examine conflicts and their possible resolution in interpersonal relationships (in Tappan \& Brown, 1989, p. 199). Tappan and Brown (1989, pp. 182) note that narrative is central to the study of morality, as well as to its teaching, and that authorship of moral choices, actions and feelings develops a sense of moral sensibility. Indeed, the deepening crisis in N orth American schools and society (see K ozol, 1991) is obliging educators to explore educational programs that encourage moral development in its students through narrative. This study offers a narrative of what can be termed a peace education initiative and involves personal and professional accounts of teachers' and students' lives in terms of moral educational issues.

O ne of the major aims of this study is to give the participants a voice and to construct meaning for their texts. I searched for the patterns and narrative threads that would bring together their lived experiences into a collective story. As participantobserver, I was concerned with the interaction between personal life histories and the shaping of assumptions about the teaching-learning experience in relation to cultural and linguistic diversity, indeed to a situation of conflict between two peoples in a land which they must learn to share. Some research questions that guided my inquiry were: 1) What perceptions of the conflict and more generally of the world do these teacher/educators bring to the classroom and how do these perceptions interact with those of the students in the class? 2) How do they envision themselves and their respective identities as J ews and Arabs caught in a very complex human struggle? 3 ) $\mathrm{H}$ ow are these views enacted in their curriculum choices and communication about peaceful coexistence within the classroom? 4) D o the schools incorporate an egalitarian multicultural philosophy into their curricula?

\section{An interactive methodology}

This inquiry was based on a strong interactive relationship between myself and my participants through dialogue and conversation. The research approach for this study therefore involved a variety of qualitative methodologies. Case study and narrative methodologies were adopted in order to document the construction and reconstruction of the meaning of teaching and learning from a moral perspective for the individual teachers, students and parents (see Kohlberg, 1985) in the specific bilingual/bicultural school setting of the village of $\mathrm{N}$ eve Shalom/Wahat Al-Salam (See C onnelly \& Clandinin, 1990; Eisner \& Peshkin, 1990; H uberman \& M iles, 1984; Yin, 1984). I therefore chose a narrative approach in order to give voice to the moral/educational initiatives that these villagers are creating. W itherell (1991) states that we "as educators 
are inescapably involved in the formation of moral communities as well as the shaping of persons" (p.239) and I highlight the phrase M axine Greene adapted from Toni M orrison's novel Beloved (1987) to say that "moral education requires becoming friends of one another's minds, even, perhaps especially, when the other is 'stranger'" (see W itherell, 1991, p. 238-9). In this process all participants were encouraged to reflect on their own personal philosophy on intergroup relations vis-à-vis the teaching and learning experience. Indeed, ethnographic and narrative research methodology was required here because of its emphasis on "thick" description, on process, and on the natural setting (i.e. the classroom, the home or the village) as the source of data (see for exampleJanesick, 1991).

Through the vehicle of narrative and case study methodology, I try to make sense of the personal as well as professional experiences of my participants in their quest for intercultural harmony. Finally, within the theoretical framework of this study, the specific educational initiative of this school as a "moral community" provides a window through which the issues of schools' relationships to multicultural and multiracial communities can be observed and elucidated more generally in a global context. I documented the experiences of the children and teachers through in-depth interviews and participant-observation in the school, and through a general "reflection-in-living" (Schön, 1991) within the village. The interviews were unstructured and as open-ended as possible. Students and teachers shared with metheir stories about why they decided to live in this village; about the dreams that they had for the children's future; about their great satisfaction with the school; and about the fragile sense of hope they nurtured for peace in their troubled land.

The discussion that follows has two levels of discourse. Firstly, it reflects my impressions of the village and the school, both the physical and psychological surroundings. Furthermore, it explores the process of narrating stories of moral development and thereby authoring one's moral lived experiences and ultimately taking responsibility for one's actions. There are a number of meta-themes that I will explore in the narrative structure of this study. They are: 1) the commitment of the participants to confront the central question of Jewish-A rab peaceful co-existence on a grassroots level within the village and school; 2) the school as a micro-society and as a moral community that can be used as a role model for conflict resolution and peacemaking; 3) the village as a model for creating a dialogue between Arabs and Jews in the larger Israeli society, in terms of instituting negotiation and compromise in an atmosphere of moral dilemma and goodwill.

\section{The two village schools: Role models for citizenship education}

W ithin the context of citizenship education, I focus on the ways that the two educational institutions in the village - the elementary school and the "School for Peace" (SFP) - both exemplify a genuine attempt at partnership between two peoples whose cultures are in geo-political and socio-historic conflict. They are innovative in their attempt to deconstruct the traditional school discourses in Israel which 
generally perpetuate the dominant/subordinate status of $\mathrm{H}$ ebrew and Arabic respectively within the curriculum. The elementary school opened its doors in 1984; the pre-school and kindergarten three years earlier. W hat is unique about this $\mathrm{N}$ eve Shalom/Wahat AI-Salam village school is that it provides the possibility for Jewish and Arab children to learn together on a daily basis in a full $\mathrm{H}$ ebrew-Arabic bilingual, bicultural setting. It is coordinated by a teaching team of J ewish and Arab educators, some of whom are residents of the village and others who commute from nearby towns and villages. The "School for Peace" conflict resolution program is geared toward bringing J ewish and Palestinian adolescents from all over Israel and the West Bank together for workshops conducted by well-trained facilitators in the village, and it has been operating since 1979. The underlying message of the elementary school and the School for Peace workshops is that it is of overriding importance to maintain personal, social and national identity for both Jews and Arabs within an egalitarian perspective. This framework assures the legitimacy of every participant's position. Indeed, it embodies the late Brazilian educator Paulo Freire's (1970) revolutionary perspective of social liberation.

$M$ y intention here is to explore those interactions among the students and teachers, emanating from their sense of shared purpose, which reflects their assumptions about the nature of education in their village and about the type of society they wish to promote through education. The school attempts to foster cooperation and mutual respect for its students of both Arab and Jewish backgrounds (Feuerverger, 1995). It aspires to be a genuine bilingual and bicultural learning environment, and could potentially provide a new and global dimension for exploring moral issues within the context of cultural and linguistic diversity and inter-group conflict. Although there has been substantial research on various aspects of language, identity and intercultural relations in many parts of the world (see for example Corson, 1990; Cummins, 1989; Feuerverger, 1991; Lo Bianco, 1989; O gbu, 1978; Samuda, 1986; Wong-Fillmore, 1991) there has been very little work on the specific consequences of bilingual and bicultural programmes in which children from majority and minority groups learn together against a larger backdrop of intergroup conflict with the ultimate goal of peaceful coexistence.

The innovative initiatives at $\mathrm{N}$ eve Shalom/Wahat Al-Salam have opened a space for reshaping the pedagogical processes in classrooms and in school policies. These initiatives are also in concert with Giroux's (1988) theoretical notion of "border pedagogy." They have made it possible for the villagers to become free to be "border crossers" and thus to challenge and redefine the limitations created by hegemonic domination. In both schools the use of $\mathrm{H}$ ebrew and Arabic is a symbol for inclusiveness and mutual understanding. They search for a new meaning to life and a better future for their children. I present some pedagogical issues that arose for my participants in their own voices. Below are several brief compilations from larger interview data:

I begin with a Palestinian teacher in the school, who explained how language awareness has offered a new pedagogical and social paradigm for the Jewish and Arab children: 
In this school Arabic and $\mathrm{H}$ ebrew both hold prominent positions and the children are fully aware of that in all classroom activities. Because each class has an Arab and a ewish teacher, the children are exposed to two points of view. For example, I teach Actualia (current events) with a Jewish teacher and we are able to discuss difficult, controversial issues immediately with our pupils. Language is such a key point here. Let's face it, learning the history of Israel in H ebrew is totally different from learning it in A rabic! Learning its history in both languages is the beginning of a whole new future. This is radical stuff! The Israeli War of Independence has a totally different connotation in Arabic and that awareness that we teachers can offer them, opens new doors for these young people.

Another Palestinian teacher in the school discussed the surprise that his father showed when he first came to visit his son in this village and met some of the children in the school:

M y father grew up in a little Arab village in the north of the country and was at first uncertain about why I should teach in a school where Jewish and Arab kids were together. H e just wasn't sure how this would work. Then on the first afternoon that he was here a little nine year old girl came up to him and spoke to him in Arabic. They had a lovely conversation and afterwards I told him this young student of mine was Jewish. H e had assumed she was an Arab because her Arabic was so fluent. When he heard she was Jewish, his eyes filled with tears and he said he thought he would never see this. H e was amazed at how all the children were getting along, jumping back and forth into $\mathrm{H}$ ebrew and Arabic. They were friends, and that was a revelation to him. That is the beauty of this place.

\section{A Jewish teacher in the school confided in me:}

I never had the opportunity as a child to learn Arabic the way the Jewish children do here. And only now do I truly realize how it changes everything to simply be able to speak to one another in both languages. It really changes things; it's very symbolic. And the children are unconsciously very aware of this, I think. I will give you a concrete example. A new child came into my class from [a nearby Jewish village] and she did not know Arabic and stayed away from the Arab children. As time went on, she of course began to interact with the Arab children and she began to learn Arabic. It was wonderful to see how her attitude changed in such a positive way. The very same is true for the Arab children who come to this school and begin to learn $\mathrm{H}$ ebrew and become friends with the ewish kids.

Another Jewish teacher was involved in a deep moral dialogue within herself and with these neighbours about arriving at the decision that her involvement in the $\mathrm{N}$ eve Shalom/Wahat AI-Salam school was the "right" thing to do. 
It wasn't easy coming back home everyday having to deal with some glowering faces. There are some in my village who feel that Arabs cannot be trusted and that they are all terrorists. So they see the school in N eve Shalom/Wahat AlSalam as idealistically foolish at best and dangerous at worst. My feeling is that if they had had the opportunity of going to such a school maybe their attitudes would be more positive. I have been trying to discuss these issues with them and some are listening but others are too far away from the idea of the possibility of co-existence. What I find wonderful about the school is the hope that these attitudes can change with these Jewish and Arab children who are learning together side by side. They are being given the opportunity to see the situation in a different way on a more equal basis.

A grade six boy from a J ewish village stated why he enjoyed learning both languages at the school:

I feel very different now that I can speak and read and write Arabic. I didn't have much to do with A rab kids before coming to this school and I was afraid of them because of all the terrorist things. But now I'm making friends with them and I can read stories about their lives and their heroes and their culture and it makes me understand them more and feel closer to them.

Zahra, a twelveyear old girl who lives in another nearby Arab village and attends the $\mathrm{N}$ eve Shalom/Wahat Al-Salam school was torn between two allegiances. She describes her moral dilemma:

In my village many of the kids got very excited about Saddam and shouted the slogans and sang the songs and I wanted to go along with them and be part of what my friends were doing. But at N eve Shalom/Wahat Al-Salam the teachers were telling us to see both sides of the problem. We have a class called actualia (current events) and both my Arab and Jewish teachers in the class talked with us for many days about trying to find peace and not war. They also explained how much better it would be if countries in the M iddle East could be friends and not enemies. $\mathrm{N}$ ot only are many Arabs enemies with Jews but many Arabs are enemies between themselves in different countries. But when I would go back home every day to my village some of my friends were mad at me becausel was friendly with the Jewish kids. At least there were some of us from my village who go to the school so we stuck together. It made me very unhappy but I wasn't alone at least. And I decided not to shout those slogans or sing those songs. M y parents wouldn't have wanted that.

A Jewish teacher reflects on team-teaching both the Israel Jewish and the Palestinian Arab narratives, as they relate to the current events classes:

I originally taught that class with Salim [who is now one of the directors of the school] and we'd just both sit together and try to thrash it out. It doesn't mean 
that you don't get differences of opinion and that it's clear sailing. It's actually very hard but there's the significance of the fact that you have a Jewish and a Palestinian teacher trying to face the issues honestly and above-board. For example, after a terrorist attack that happened one morning in Jerusalem, Salim was directing the class and he brought out the issue of who profits from this type of activity. $\mathrm{H}$ e said how it just increases the hatred and gives more power to the right-wing groups. The fact that an Arab teacher said that obviously meant something. It has an effect on both the Jewish and the Arab kids in the class. It opens up a line of communication, of real dialogue.

A Palestinian teacher explained the role that the school plays in enhancing a positive sense of identity for its students and commented on the moral development that is embodied within the daily educational discourse in the classes:

The Arab children who come to this school feel so much better about themselves. They feel a sense of equality here with the J ewish students. It really is a wonderful thing. There are very few places where this happens on a formal and every-day level. In most cases Arabs feel very marginalized within Israeli society. In this school the children are able to share their stories and their experiences; their fears and their hopes. I think this school and this village is the hope for the next generation. There are all sorts of examples I can give you that would show how difficult moral issues are treated in the daily class lessons. The students and we the teachers live these problems all the time and they are there in every aspect of our teaching and learning.

I spent one morning during my first sojourn in the village in the grade one class with Arifa. Shelives in a nearby Arab village and commutes to the school every day. She is a natural teacher and all the children love her. She explained to me how important it is for a teacher to see the child first - not their cultural background:

You must see them with open eyes for the special qualities they have inside them. You must give them a chance to show you their unique self. And then I deal with whether they are Arab or Jewish. But only after we really get to know each other. I try so hard to keep an open mind. N obody says it's easy. But it makes such a difference.

In her class, the children were collectively preparing their songs, poems and stories for the $\mathrm{C}$ hristmas party that was fast approaching. The atmosphere was festive and industrious. In this class $\mathrm{H}$ ebrew and Arabic were being used simultaneously. The children, guided by their teacher, were crafting themes revolving around war and loss and a hope for peace and normality. The class activities and discussions reflected the actual experiences that the children must deal with in their everyday lives. Their contributions to the curriculum were evident in this lesson. In fact, the teacher and her students shared in the development of the lesson and thus participated in the construction of knowledge and understanding of difficult moral issues within the larger 
social-political context in which they were situated. A few children recited this poem in Arabic, $\mathrm{H}$ ebrew and English:

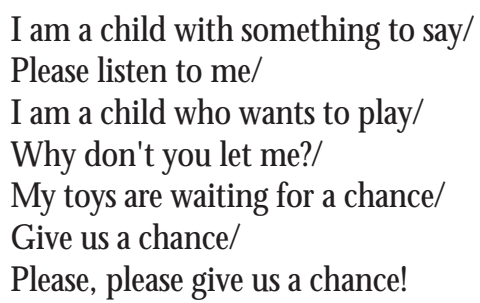

W hat was remarkable about this presentation was that the children, Jewish, M uslim and Christian, were singing in unison for peace and understanding: "We don't want guns, we want music and feasts and gifts from Baba N oel on this holiday." There was magic in this classroom. Suddenly I felt as if I was in a sacred place. At that moment, I knew I didn't want to be anywhere else on this earth. I thought of how in Judaism, the $\mathrm{H}$ oly Book or Torah explains that each and everyone of us has our own distinctive contribution to make in order to help repair the world. It is called Tikkun $\mathrm{H}$ aolam in $\mathrm{H}$ ebrew and it is a very empowering idea in its call to action on this earth. Idealistically, $\mathrm{N}$ eve Shalom/Wahat Al-Salam embodies this philosophy, which allows every human being to feel that they can and will make a difference on this earth according to their special talents and nature. I was impressed with these children chattering away in $\mathrm{H}$ ebrew and Arabic, helping each other with their lessons, laughing together, playing together. I looked at the teachers, Arab and Jewish, planning and teaching lessons together, examining each other's point of view on some very thorny issues in history and current events. I witnessed the healing power of singing, story writing, artwork, music and drama in the classrooms.

\section{The Christmas party: Inter-faith understanding as an experiment in citizenship education}

This section is devoted to the Christmas party, which took place on the last day of school at the end of term during my first sojourn in the village. This event again exemplifies the moral enterprise in which these people are engaged on a daily basis. The narrative below attempts to draw a picture and interpret the details of the gathering from my personal and professional perspective as researcher/observer. I offer the following excerpt from my journal entry about the school party:

The Christmas party was scheduled to begin at 5 p.m. in the kindergarten; and 6 p.m. in the elementary school. I was told that it would be special because many parents would be meeting each other for the first time. This is because this is the first year where children from villages near $\mathrm{N}$ eve Shalom/Wahat AI-Salam are attending the school. The school, therefore, is growing and that is such a positive sign. By 4 o'clock in the afternoon the whole village was buzzing with anticipation. I had hoped to take a short nap before the parties but the euphoria 
was contagious. I ended up going over to Joel and M argalit's place and helped them dress their two daughters. They looked like two little dolls in pink and purple. We got to the kindergarten at 4:45 p.m. and it was al ready a mob scene. N othing had prepared me for what I was about to witness. Parents were taking their first steps towards one another and friendship. In most cases, I could not tell who was Jewish and who was Arab, except, of course, for those who wore traditional outfits. Some held back shyly; some moved forward easily in the crowd. Everyone sensed that they were part of something very special. M y eyes fell on an Arab woman in her veil sitting with a lovely little baby on her lap. Right next to her was a Jewish woman also sitting with a little child on her lap. They began to chat about their children in the kindergarten. "T his is what peace is all about", I remember saying to myself. I was disgusted with the world's media for only focusing on the negative and on distortions and sensationalist manipulations. W hy do we never hear about these peace efforts?

A hush fell over the crowd as the two kindergarten teachers entered the room and began to narrate the $\mathrm{C}$ hristmas story in $\mathrm{H}$ ebrew and Arabic. As the story progressed, the children entered in their costumes. "M iriam", "Yosef" and "Yeshua", the baby in $M$ ary's arms, emerged from the side. Little five-year-old "M iriam" was breathtaking in her white cape and veil, hugging her little baby doll all covered up in a blanket. Then, the innkeeper; the stable with the animals; the three wise men; angels, and so it went. Each child had a little piece to say. Their brothers and sisters in the audience along with their parents looked on proudly. It was a boisterous, happy crowd. M y eyes filled with tears. $\mathrm{H}$ ere in this little village not very far from Jerusalem - a place little known to the rest of the world - was the true spirit of Christmas: Jewish and Arab children performing the Christmas story in their classroom with their families sitting side by side in the audience. $\mathrm{H}$ ere was the $\mathrm{C}$ hristmas message as it had been originally meant. GOO D W ill to ALL H umanity (Christians, Jews, M oslems, EVERYBO DY!). I snapped my photos but the scene was blurry in front of my watery eyes. I don't think anyone noticed my tear-stained face as we all moved out towards the elementary school. Every one was busy in friendly conversation.

There were many more parents in the large elementary hall. M ore lively conversation. $\mathrm{M}$ any of the parents from the neighbouring villages knew who I was because their children had come home talking about me over the past week. The atmosphere in the room was so congenial. The two school co-directors welcomed the parents and described the evening program. Suddenly the lights were closed and in the darkness the children began to approach the front of the room with candles. The girls were dressed in splendid palecoloured dresses, some chiffon or satin or lace. They had large bows or flowers in their hair. M ost of the outfits had been sewn by their mothers. The boys looked neat in freshly pressed pants and shirts. They were all so magnificent. The image that came to my mind was that of a beautiful ballet where each dancer knew their role and performed gracefully. The whole audience was transfixed. There was music and song and dance and story. I wished that the evening would never end. I felt like a child in a candy shop, tasting all these goodies. The 
presentation ended with a dramatic entrance by none other than Baba $\mathrm{N}$ oel who distributed gifts to all the children. I will never forget the "bilingual and bicultural" laughter and good cheer that evening (Winter, 1992).

I remember saying to myself during the flight back to $C$ anada: "Perhaps this little village in Israel has the potential to become a model for conflict resolution and peacemaking." I came away from that first sojourn in this little "oasis" with a sense that there is no possibility of achieving peace without facing the ravages of war. Indeed, the power of narrative may lie in allowing the suffering of the "other" to become part of our own consciousness, part of how we perceive the world. Perhaps it is only through the telling and retelling of stories of war, trauma and violence that a liberation and transformation towards global emotional recovery can take place. Indeed, in a village like N eve Shalom/Wahat AI-Salam where there is a sense of safety and good-will, the sharing of stories of pain can transform feelings of fear and hopelessness into those of compassion and reconciliation. At least they are trying. When I asked some of the children in the school what they would like me to tell others about their way of life, they responded with these words:

It is very easy to call people names and to hate them. But when you begin to live with them and go to school with them and play with them, then you realize that, even though they may have different customs and beliefs, they are really very similar in many ways. You have to find a bridge and meet them halfway.

This, in my view, is citizenship education as it is meant to be.

\section{The "School for Peace" : The beginning of coexistence}

$M$ y intention in this section is to explore this School for Peace as an outreach conflict resolution program that conducts educational encounters bringing Jewish and Palestinian adolescents together from all over Israel, and increasingly from the West Bank. The underlying message of the SFP is that it is of utmost importance to maintain personal, social and national identity for both Jews and Arabs. In this paper, the author offers a reflective analysis of what conflict resolution means for these participants within the specific context of the Jewish-Palestinian conflict, which has implications for citizenship education and peace education both locally and internationally. As participant-observer in a number of workshop sessions, the author explored the multiplicity of tensions situated in the narratives that emerged within the safety of these workshops.

The stories that I heard were sacred and had to be honoured within the context of this peacemaking enterprise. The continual refrain of victimhood echoed throughout the narratives that emerged within the safety of these workshops. In the midst of their dialogues and journal writing, the students became more familiar with their unique, personal perceptions of their place in society, their search for justice in this conflictual existence, and in which ways they might contribute to changing the status quo, at least 
in their own minds. The complexity of identity al ways pervaded their narrative inquiry. D iscussing subjective perceptions of ethnic, national and linguistic identity involves a great deal of personal reflection, which strikes at the very core of how we define ourselves in the world. The students discovered that it is all tied into their sense of purpose and self-worth in society. Through the sharing of their journals, they heard the voices of the "other" within lived experiences and as a result of this influence, their own stories were reconstructed and re-told in a fresh new perspective. Below are several excerpts from interviews during the three-day intensive workshop:

After an arduous discussion about the social injustice in the occupied territories, Temada, a Palestinian female participant, said:

It's about time that we Palestinians are able to show our anger about the situation. When I think about what is going on in the Territories - and I have relatives there who are suffering daily - I want to scream.

Ronit, a Jewish female participant sighed in relief as she explained what she felt was important about these workshops:

These workshops don't just deal with dry theoretical material, but confront the conflict head-on through a very experiential approach. So many people feel a sense of powerlessness and anger in our society. That kind of frustration is so deadly. And yet we're all afraid to really talk about it from our hearts. We're discussing the effect that all the terrorism has on each of us personally. I have hardly ever discussed that in my regular classrooms. It's too overwhelming. So we try to bravely go on after every attack. But inside our hearts are being torn up. We still feel like the persecuted Jew deep inside.

M ordechai, a J ewish male teenager confessed in the middle of the first day:

Before this workshop I was embarrassed to show emotions; to speak about love, sympathy - about how afraid I am to go into the army and to have to deal with what is going on in the territories. The fact that the course focused on both emotional rather than merely rational elements helped me with this. Today I will not hesitate to say what I feel.

Rafiq, a male Israeli Arab, captured the mood of the workshop:

I always had the feeling that the Jews in Israel were so confident about their place in the world. It comes as quite a revelation to realize that underneath their external bravado, they have terrible feelings of being in exile and feel so worried because of their history of persecution. It's so strange to learn this. I've had some personal discussions with some people here that I will never forget, no matter what happens. It is really quite a strange mess.

The Gulf War, which took place in early 1991, also underscored the differential emotional reaction of Arabs and Jews (and here I am speaking of those who are al ready 
committed to peaceful coexistence) towards the reckless behaviour of Saddam H ussein. At the end of the day, Tirzah described how the events of the Gulf War deeply affected her:

There was a sick feeling that overcame me in my sealed rooms meant to protect us against the toxic chemicals that Saddam promised to deploy with the missiles. $\mathrm{H}$ e boasted that he would burn half of Israel! The feeling went straight back to the gas chambers of the concentration camps where many of our relatives were murdered. We ews shared in a collective fear. It was a totally different experience emotionally for the Arabs. As if we, both Arabs and Jews, were in the same room but watching two totally different films!

Ahmed, the Palestinian facilitator, added:

The Holocaust was an event of such horror and magnitude that of course, we Palestinians can't compete with that kind of suffering. But I think that the Jews have to get past that and acknowledge our own pain. Saddam, rightly or wrongly, came across at the beginning of the G ulf War as a leader in the M iddle East who could restore our badly broken Arab identity and pride. M any Palestinians were entranced by that. It is important to realize just how low and injured we feel. I hope we can get over this "gulf" - literally. We [the Jews and Palestinians] have to keep talking and listening to one another.

A Jewish participant's reflections at the end of the third day are relevant to this discussion:

Trying to find a route to peaceful coexistence is a very radical political act. You look at this country where there is so much hatred and fear and a closing of the mind. For the most part, the Arabs live in their villages and we live in ours, side by side. And each one creates their own fantasies and myths about the other, all embroidered with fear. In this workshop, I feel as if some of those myths are being broken down and we are examining one another directly. We have escaped from our "ghettos" and I think that's radical. It's an authentic encounter. There have been some horrible arguments in these workshops but in spite of the fact that we're still far from having solved the problem, I personally feel less despairing. Because nobody forced the other to give up their identity. There were times when we got past the power games and that was incredible.

And below are excerpts from two students right at the end of the third day. A Jewish female participant summed it up:

We're both drowning in quicksand next to each other but can we stretch out our hands to one another or will we sink in the mud with our raised fists?

That last evening the students enjoyed a social gathering filled with laughter, and traditional Arab and Israeli dancing and singing. They exchanged telephone numbers and addresses. The next day, in the morning fog, they slowly bid one another goodbye, tears in many eyes. I asked a Palestinian girl whether she thought 
this workshop would make a difference. She confided to me as she climbed onto the bus:

It has al ready made a difference. Something in me has changed. We may not have solved the problem, but I come away with a real treasure - my heart is now filled with less hatred and instead there's a greater understanding of how complicated this conflict is. I saw what's behind the mask of my enemy. I think the process has to start from there.

In spite of this existential tragedy of conflict between the two peoples, their language in the SFP workshops travelled from the margins of the web of enmity in which they were entrapped to the centre of the discussion - where their discourse created a sense of belonging in their common suffering, rather than in a competition of suffering. A kind of blended story of victimhood began to emerge. In other words, they began to recognize in the other's narrative, their own story and the interconnected themes of displacement and strangerhood which brings the wandering Jew and Palestinian together from their arid terrain of enmity and despair. The intertwined destinies of Ishmael and Isaac now stared one another in the face. They began to name the historical sources of their conflict, and to name is to gain power through language.

\section{Concluding remarks}

I have tried to present some examples of a collective moral dialogue - both enheartening and excruciating - which has been weaving its way into the lives of each individual and into the very fabric of this community. It may very well be the case that these schools and this village have an important role to play in the moral education of culturally diverse communities in conflict, not only in other parts of I srael, but also in the international arena. Indeed, the ongoing quest for peace and equality, evidenced through their personal, social and educational activities, provides the villagers with countless opportunities to interpret and contemplate their cultural and historical destinies. Their stories are simple and complex, ordinary and extraordinary, mundane and heroic, foreign and familiar, full of tension and of pain, but also of hope. I feel honoured to have been among them.

From its very beginning, this inquiry is a shared experience which intended to validate all participants (including myself as researcher) and empowers us to explore the meaning of "moral community" within the context of the N eve Shalom/Wahat Al-Salam School. The uniqueness of this school is based on a genuine attempt at partnership between two peoples whose cultures are in geo-political and sociohistoric conflict. M y intention was to explore the ways in which discussion, moral negotiation and collaborative decision-making formed a basis for creating a spirit of community within the village and in the schools. The main goal of this study therefore was to explore the ethos of the school as embedded within the larger social organization of the village. I wanted to describe the interconnected settings of school and village as a 'moral community' within a larger social-political setting of inter- 
group conflict. O ne major focus was on the moral perspectives of the participants in $\mathrm{N}$ eve Shalom/Wahat Al-Salam who are involved in a highly innovative discourse of peacemaking through education.

The village and its schools as a "moral" endeavour appears to reflect the need for bringing about an understanding of the self in relation to the other, in terms of J ewish and Palestinian conflict resolution. It is this quest for understanding between the two cultural and national groups and for awareness of the complexity of the Jewish-A rab issue that is at the heart of the peaceful co-existence between the villagers. In allowing my participants to share their voices with me, I struggled to understand the moral dilemmas and complex interrelationships in their lived experiences. As a result of the constant social and political tensions that arise out of the Jewish-Palestinian conflict, moral negotiation in the village continues at all levels of discourse. I was struck by how the villagers were constantly negotiating the space between the tensions of competing national aspirations and their personal attempts at co-existence and good-will. In spite of all the moral complexities and conflicts, my researcher self became more and more convinced that, at bottom, this was a caring educational community that was dedicated to peaceful co-existence. It may very well be the case that this school has an important role to play in the moral education of culturally diverse communities not only in other parts of Israel but also in the international arena. Indeed, the ongoing quest for peace and equality, evidenced through their personal, social and educational activities, provides the villagers with countless opportunities to interpret and contemplate their cultural and historical destinies.

I firmly believe that one of the most important contributions we can make as academics is to use the vehicle of our research work as a means of forwarding the cause of peace and equality within an anti-racist, multicultural and multilingual educational context for all societies, and to unequivocally support an inclusive curriculum wherein all forms of oppression can be addressed with compassion. U Itimately, educational and all forms of human reform are dependent on the importance and power of love: I cite here Freire's (1994) universalist message:

Dialogue cannot exist, however, in the absence of a profound love for the world and for people... Because love is an act of courage, not of fear, love is commitment to others. No matter where the oppressed are found, the act of love is commitment to their cause - the cause of liberation... As an act of bravery, love cannot be sentimental: as an act of freedom it must nor serve as a pretext for manipulation. It must generate other acts of freedom; otherwise, it is not love.

I am comforted and empowered by the philosophy of Freire and in the knowledge and belief systems of mindful, compassionate scholars everywhere who stress that "cultural workers must create alliances across national borders... and that, in Freirian terms, revolutionary love is always pointed in the direction of commitment and fidelity to a global project of emancipation" (M CLaren, 1999, pp. 53-54).

This article rests on the basic assumption that citizenship education (and indeed all educational research) must depend upon compassion as well as knowledge. Thereare 
those in the academy who are in the midst of poststructuralist debates about what is real and what is representational in educational research. I believe, as a peace worker, that the authentic debates are those in which theory and practice are sculpted into an educational discourse devoted towards the striving for conflict resolution, moral integrity and a true respect for diversity; a respect for all humanity in the name of those who have suffered and those who continue to suffer at the hands of oppression all over the world. N eve Shalom/Wahat Al-Salam is one example of those courageous few who rise up above the fray and say: 'we must come together to teach and learn about how to find an end to violence, poverty, oppression and war, no matter what colour of the rainbow we happen to be, and no matter where we are coming from.' The ultimate goal of this research work is to bear witness to the power of what these villagers are trying to accomplish in this place. Their educational enterprise is an exchange; a relationship that involves giving and receiving - the dream of a more just society and the promise of hope.

\section{References}

Bakhtin, M . (1986). Speech genres and other late essays. (V. M cGee, Trans.). Austin, T X: U niversity of Texas Press.

Connelly, F.M . and Clandinin, D .J. (1990). Stories of experience and narrative inquiry. Educational Researcher, 19(5), 2-14.

Corson, D . (1990). Language policy across the curriculum. Clevedon, Avon: M ultilingual $M$ atters.

Cummins, J. (1989). Empowering minority students. Sacramento, C A: California Association for Bilingual Education.

Eisner, E. and Peshkin, A. (1990). Q ualitative inqui ry in education: T he continuing debate. N ew York: Teachers College, C olumbia University.

Feuerverger, G . (1991). U niversity students' perceptions of heritage language learning and ethnic identity maintenance in multicultural Toronto. Canadian M odern Language Review, 47(4), 660-677.

Feuerverger, G . (1995). 0 asis of peace: A community of moral education in Israel. Journal of $M$ oral Education, 24(2), 113-141.

Freire, P. (1970). Pedagogy of the oppressed. N ew York: Seabury Press.

Freire, P. (1994). Pedagogy of hope: Reliving pedagogy of the oppressed. N ew York: Continuum Press.

Geertz, C . (1988). Works and lives: Theanthropologist as author. Stanford, CA: Stanford U niversity Press.

Gilligan, C. (1982). In a different voice: Psychological theory and women's development. Cambridge, M A: $\mathrm{H}$ arvard University Press.

Giroux, H . (1988). Schooling and the struggle for public life. M inneapolis, M N : University of $M$ innesota Press.

H uberman, A.M . and M iles, M .B. (1984). Innovation up close. N ew York: Plenum.

Janesick, V. (1991). Ethnographic inquiry: Understanding culture and experience. In E. Short (Ed.), C ritical inquiry (pp. 101-119). N ew York: StateU niversity of N ew York.

Kohlberg, L. (1985). The just community approach to moral education in theory and practice. In M. Berkowitz, \& F. O ser (Eds.), M oral education: T heory and application (pp. 27-87). Hillsdale, NJ: LawrenceErlbaum.

Kozol, J. (1991). Savage inequalities C hildren in America's schools. N ew York: Crown.

Lo Bianco, J. (1989). Revitalizing multicultural education in Australia. M ulticulturalism, 12(1), 30-39. 
M CLaren, P. (1999). CheG uevara, Paulo Freireand the pedagogy of revolution. Lanham, M D: Rowan \& Littlefield.

M orrison, T. (1987). Beloved. N ew York: Alfred K. Knopf.

N oddings, N . (1991). Stories in dialogue: Caring and interpersonal reasoning. In C. W itherell, \& N. N oddings, (Eds.), Stories lives tell: N arrative and dialogue in education (pp. 157-170). N ew York: Teachers College Press.

O gbu, J. (1978). M inority education and caste. N ew York: Academic Press.

Polkinghorne, D.E. (1988). N arrati veknowing and the human sciences. Albany, N Y: State University of $\mathrm{N}$ ew York Press.

Samuda, R. (1986). The Canadian brand of multiculturalism: Social and educational implications. In S. M odgil, G. K. Verma, K. M allick \& C. M odgil (Eds.), M ulticultural education: The interminable debate (pp. 101-109). Philadel phia: The Falmer Press.

Sarbin, T.R. (Ed.) (1986). N arrative psychology: The storied nature of human conduct. N ew York: Praeger.

Schön, D. (Ed.) (1991). The reflectiveturn: Case studies in and on educational practice. N ew York: Teachers College Press.

Tappan, M . and Brown, L. (1989). Stories told and lessons learned: Toward a narrative approach to moral development and moral education. H arvard Educational Review, 59 (2), 182-205.

W itherell, C. (1991). N arrative and the moral real m: Tales of caring and justice. Journal of M oral Education, 20(3), 293-303.

Wong-Fillmore, L. (1991). Language and cultural issues in the early education of language minority children. In S. L. Kagan (Ed.), The careand education of America's young children: O bstacles and opportunities (pp. 30-49). Chicago: N SSE, U niversity of C hicago Press.

Yin, R.K. (1984). Case study research. London: Sage. 